Migration Studies - Review of Polish Diaspora nr 4 (174)/2019, http://www.ejournals.eu/Studia-Migracyjne/ DOI: 10.4467/25444972SMPP.19.045.11359

\title{
A Dream Job or Any Job? \\ The Career Paths of Polish Migrant Women Working in Norwegian Kindergartens
}

\author{
ELŻBIETA CZAPKA ${ }^{1}$ \\ Oslo Metropolitan University
}

After Poland's accession to the European Union and the opening of the Norwegian market for Polish employees, the gender structure of Polish migrants in Norway changed radically. The number of men increased rapidly in relation to the number of women due to the demand of the Norwegian labor market for employees in the construction industry. For several years, the number of women has been growing slightly faster than the number of men due to family reunification. Poles living in Norway are relatively young and well-educated. Research carried out so far indicates that Polish migrants experience many problems finding employment that is in line with their education (Czapka 2010; Huang, Krzaklewska, Pustulka 2016).

The article presents partial results of qualitative research carried out in Oslo in 2015 among Polish assistants working in Norwegian kindergartens in the framework of the project "Barnehagen som tillitsarena: hvordan lages den flerkulturelle samfunnskontrakten?", which is part of the Polish-Norwegian project POLFAMIGRA ("Polish female migrants and their families - a study of care deficit ").

The research results indicate that the work of an assistant in a kindergarten is for many Polish women the next stage in their professional careers in Norway and is often perceived in terms of career advancement. For the part of women participating in the study, work in the kindergarten was to be only a temporary type of employment, which was to ensure their income until they find a job consistent with their education. Most of them believed that their work does not enjoy high social prestige and is associated with relatively low wages.

Key words: Polish migrants, Norway, career paths, kindergarten assistants

\footnotetext{
1 Contact: elzbi@oslomet.no
} 


\section{Introduction}

Poles have constituted the largest group of migrants in Norway for several years. According to SSB (Statistics Norway), there are nearly 100,000 registered Polish nationals in Norway (SSB, 1/01/2019). Thus far, no large scale return of Poles to Poland has been observed. Despite the fact that many of the recently arrived, post-accession migrants find employment in precarious segments of the labor market, many of them have opportunities to find work that provides them with more predictability and better conditions (Bygnes, Bivand Erdal 2016). The popularity of Norway as an immigration country stems from the relatively easy access to employment and the availability of a wide range of social benefits.

According to SSB data, there were 961 men and 1,780 women of Polish origin in Norway in 2004. After Poland's accession to the European Union and the opening of the Norwegian market to Polish employees, the gender structure of Polish migrants changed radically. The number of men increased rapidly in relation to the number of women, due to the demand for employees in the construction industry in the Norwegian labor market. For several years, the number of women has been growing slightly faster than the number of men, due among others to family reunions. Polish women living in Norway are relatively young (16-19: 1,137, 20-29: 7,112, 30-39: 11,339, 40-49: 4,399, 50-66: 2,065, 67 and more: 103). ${ }^{2}$ According to Statistics Norway, $72.3 \%$ of Polish female immigrants were employed in 2017, compared to $79.1 \%$ male immigrants (SSB, 2017). The percentage of employed women increases with the length of stay in Norway (SSB, 2017).

Polish immigrants in Norway tend to do jobs which are not eagerly taken on by Norwegians but are also considered less prestigious in Poland. In literature they tend to be referred to as 3D jobs (dirty, dangerous and dull/difficult/demanding), (Favell, 2008). According to research carried out in 2006, as part of the project "Polish migrants in Oslo", the labor market for migrants from Poland was extremely gendered (Friberg, 2010). Men worked mainly in the construction sector and in the oil industry. However, the crisis in the oil industry led to a drastic fall in workplaces and resulted in growing levels of unemployment among Polish men. Two out of every three Polish women working in Oslo were engaged in cleaning occupations (Friberg, 2010). As many as $84 \%$ worked illegally or semi-legally (ibid.). A small number of Polish female migrants worked in kindergartens and in health services. It should be noted here that female migrants who followed partners already working in Norway experienced many difficulties related to finding jobs, regardless of the level of their education.

The existing literature on economic migration most frequently refers to the concept of skilled and unskilled migration, indicating the completely different experiences

2 Author's own elaboration based on SSB data. 


\section{SM̂PP}

of both groups of migrants. Parutis discusses problems with the categorization of Polish post-accession migrants as skilled or unskilled (Parutis 2011). They are often well educated, highly skilled individuals, but accept low-skilled and poorly paid jobs because they need to support themselves financially (Parutis 2011). Parutis uses the term "middling transnationalism ", developed by Conradson and Latham (2005), to describe a type of migration which eludes previous categorizations. Research conducted among Polish women in the United Kingdom shows that in the case of migration, we are not always confronted by downward social mobility and brain drain (Aziz 2015). Many post accession migrants will be promoted at work over time. They start their own companies, something typically associated with occupying an increasingly higher position in the social structure. Researchers point out that gender differentiates the approach to migration (Grabowska-Lusińska, Jazwińska-Motylska 2013). Women are more determined to search for a job and they react differently to the structure of opportunities in the country of immigration. ${ }^{3}$ Unlike men, who are conformists, women are characterized by more innovative attitudes and adapt faster to changing conditions (ibid.: 107).

The qualitative data presented in this article was collected as part of a lager study "Barnehagen som tillitsarena: hvordan lages den flerkulturelle samfunnskontrakten?" (Kindergarten as an arena of trust: how to create a multicultural social contract?). The article presents and discusses Polish female migrants career paths and barriers to access to employment.

\section{Method}

A qualitative methodology framework was used to permit the author to explore Polish female migrants' experiences related to work in Norwegian kindergartens. The study was performed in Oslo in 2015. Oslo was chosen because it has the largest population of Polish migrants among the Norwegian cities. The snowball sampling method was used to recruit the study participants. The interviews took place at places which were convenient for the participants: private homes, university, parks and cafes. They were conducted by the author in Polish. The duration of the interviews varied from 45 minutes to 2 hours. One of the interviewees did not consent for the interview to be recorded due to past bad experiences related to participation in a research project. In this case, the researcher made as accurate notes as possible.

The interviews were conducted using a semi-structured interview guide that allowed the interviewer to tailor the questions to the interviewee and to the interview

${ }_{3}$ Researchers refer to the concept of opportunity structure, as implemented by Robert Merton, to sociology. It explains how the organization and structure of the society influences individual pathways to success. 
context. A framework of themes was developed based on the results of previous studies and was adjusted as a response to the participants throughout the study.

Throughout the entire research process, the author had to negotiate her insider/ outsider position (Pustułka, Bell, Trąbka 2019). Being an insider, "one of them", was an advantage during the recruitment process as it facilitated an access to the Polish community and helped to build trust. During the interview, the author was often perceived by the participants as an outsider. They said: "you have a different job so you can't imagine...", "you are probably more integrated in the society here". Some participants needed multiple assurances that researcher would not pass on any information obtained during the interviews to their employers. At the same time, they emphasized that they could not talk about all aspects of the functioning of the kindergarten due to the confidentiality clauses they had signed.

Except for one individual, all participants had completed a university education (Table 1). They came to Norway for various reasons, not necessarily economical. Previous studies conducted among post-accession migrants confirm that these are not always migrations aimed at earning money. In the case of young, unmarried people, migration is often a way to gain new experiences and explore a new culture.

Socio-demographic characteristics of the participants.

\begin{tabular}{|c|c|c|c|c|c|}
\hline & age & education & $\begin{array}{c}\text { Length } \\
\text { of stay } \\
\text { in Norway }\end{array}$ & $\begin{array}{l}\text { Duration } \\
\text { of employment } \\
\text { in kindergarten }\end{array}$ & Reason for migration \\
\hline 1 & 34 & university & 8 years & 3 years & desire for adventure \\
\hline 2 & 32 & university & 8 years & 4 years & desire for adventure \\
\hline 3 & 37 & vocational & 4 years & 1 year & family reunification \\
\hline 4 & 34 & $\begin{array}{l}\text { university } \\
\text { (education) }\end{array}$ & 10 years & 5 years & $\begin{array}{l}\text { curiosity, fear of looking for } \\
\text { a job in Poland }\end{array}$ \\
\hline 5 & 33 & university & 6 years & 1 year & $\begin{array}{l}\text { an accident (the participant } \\
\text { didn't plan to stay in Norway) }\end{array}$ \\
\hline 6 & 33 & $\begin{array}{l}\text { university } \\
\text { (education, } \\
\text { psychology) }\end{array}$ & 3 years & 4 months & $\begin{array}{l}\text { curiosity - what is it like to } \\
\text { live in another country }\end{array}$ \\
\hline 7 & 31 & university & 7 years & 5 years & husband got a job in Norway \\
\hline 8 & 46 & university & 5 years & 2 years & financial problems \\
\hline 9 & 33 & $\begin{array}{l}\text { university } \\
\text { (education) }\end{array}$ & ------ & 5 years & desire to live in Norway \\
\hline 10 & 42 & university & 8 years & 2 years & Norwegian husband \\
\hline
\end{tabular}




\section{SM̂PP}

All the interviews were tape recorded, transcribed verbatim and translated into English. The transcripts were anonymized. They were coded manually, categorized, and analyzed thematically, in accordance with a six-phase approach to thematic analysis (Braun, Clark 2006). In the first phase, the interview transcripts were read two times to obtain a thorough overview of the data. In the second phase, the initial codes were assigned to the text. In the third phase, the codes were clustered into themes. Subsequently, the initial themes were reviewed in order to assure the coherence of the data within the theme and a clear distinction was discernible between the themes. In the last phase, the data within each theme were analyzed, and subthemes within each theme identified.

The study was registered at the Norwegian Centre for Research Data. All the interviewees gave informed consent for their participation in the research.

\section{3. "Quite decently, they even wanted to sign a contract with us" - first experiences of the Norwegian labor market}

In the case of economic migration, we often encounter the type of mobility described in the literature as contradictory class mobility (Parrenas 2015, Morokvasic 2003). This means an increase in social status in the country of emigration and a degradation of status in the country of immigration. This "degradation" is often part of the migration plan. According to Trevena, who explored the migration of Polish university graduates to the UK, the decision to migrate "is usually bound with a cost in the form of undertaking work decidedly below their level of qualifications" (Trevena 2011: 72). Despite de-skilling, migrants improve their economic situation, learn the language and open up to new opportunities for their own development in the country of immigration.

Some of the participants admitted that they had anticipated fewer problems with finding work. One of them explained: "I thought that somehow it would be ... it would be easier in my professional career. That was the only thing that hasn't really worked out" (6). Almost all of the study participants experienced deskilling in Norway. In the case of many of the participants, the work of cleaners, sometimes done illegally, was the first stage of a professional career in Norway. Demand for employees in the cleaning services sector was very large and it was also often the only opportunity to get a job without language competences or the authorization of a diploma obtained in Poland. During the interviews, 3 participants pointed out that they did not have the opportunity to learn the language before leaving Poland. Norwegian, unlike English, was not a language that would be widely taught in Poland.

The participants who were asked about the beginning of their work in Norway answered: 
"What was my first job? The same as in case of most of us here. I started by cleaning people's houses. All my friends were doing the same." (2)

"When I got back [from Poland] another friend of mine started giving me her cleaning shifts. So I cleaned for another two years. So I worked out a system, [being paid] under the table, of course..." (4)

Participants' statements indicated that they treated cleaning as a first "regular" job in Norway. Although most women started their life in Norway in a similar way, the experience of working in the cleaning sector was very diverse. The story of one of the interviewees shows the exploitation that was associated with her initial employment:

"You know, it was about six or six and half to seven hours. Horrible, horrible. When I looked at this Lithuanian girl on her hands and knees, to be faster and faster. She had a degree in psychology. I was literarily in shock. I was able to keep up for a week, of course. But I thought to myself "God, this isn't work for a human being". It's... we were paid, I think, 120 kroner per hour. Quite decently, they even wanted to sign a contract with us.... And then I was looking for a job again. In a way, I found a more stable job, by going from pub to pub. I ended up as a waitress. Never would I have thought, in Poland, that I could work as a waitress...They wanted to hire [someone] with English, ok. Not to mention that we were exploited again. 70 Kroner per hour. And I signed a contract. But they didn't register me." (8)

More of the participants experienced exploitation at work. Because of the need to provide for themselves, their lack of knowledge about the language or labor law, many Polish women accepted the situation as it was. They were afraid to lose the job and the only source of income. It should be noted that Polish migrants also had their share in maintaining the illegal nature of work. In a café next to one of the churches, the author often saw announcements concerning "Addresses for cleaning for sale", "I will sell the addresses of the houses to clean". For some time, the authorities have been trying to regulate the situation of employing illegal workers in cleaning companies. Campaign have been conducted to persuade the clients of these companies that they are responsible for checking whether the person performing the work is legally employed. Minimum wages were also introduced for employees in the cleaning services sector.

Not all of the participants started their careers in Norway as domestic workers. One of the women was legally employed as a babysitter for several years. She did not need to know Norwegian but she was aware of the temporary nature of her employment and she invested her time and money in learning Norwegian. Two of the women participating in the study could not find any employment for a longer period of time and were supported by their husbands with jobs in Norway. They learnt the language during this period and finally began working as assistants in 


\section{SM̂PP}

Norwegian kindergartens. The next part of the article presents the experiences of research participants associated with working in a kindergarten, primarily focusing on job satisfaction and relations with other kindergarten employees.

\section{Work at a Norwegian kindergarten}

Undertaking work in a kindergarten was perceived as a kind of promotion for most of the participants, although most often it was not employment that was in line with their education. The research results indicate that this work was one of the few earning opportunities available for post-accession Polish female migrants. At the same time, it was a job with greater prestige than work in the cleaning sector. Research shows that the participants had different paths to employment in kindergartens. One of them had first worked in a bakery, then cleaned and subsequently worked in a clothing store. She was afraid to take up alternative employment due to her poor language skills. When she learned about the course for kindergarten assistants organized by NAV (the Norwegian Labor and Welfare Administration), she decided to apply and, after completing her internship, she was offered a permanent job in a kindergarten. Another woman received a job offer as an assistant in a kindergarten where she had previously cleaned. Interestingly, only one participant had decided to work in a kindergarten before coming to Norway. In Poland, she had completed a three-month Norwegian language course organized by Adecco. ${ }^{4}$ In Norway, she first worked in a kindergarten but because of experiencing problems with getting her salary, the woman returned to Poland but only stayed for 2 months. During the interview she admitted: "I no longer fit in Poland. Everything changed there". After returning to Oslo, she easily found a job at another kindergarten. In the case of another participant, work in a kindergarten constituted a natural continuation of her previous work as an au pair. The woman felt well prepared to work with children:

"I started working there because I think I'm suited for this job. I have a way with children,

I understand them, they like me. I'm a responsible person and I'm suited for this, yes,

I can take control of the situation, I'm experienced." (1)

Many participants worked as vikarer (temporary substitute workers) at the beginning, something associated with low income, open availability requirements and stress related to job uncertainty. The ones who attended the courses organized by NAV for kindergarten assistants, usually started with an internship in one of the kindergartens. If all went well, they signed a job contract afterwards. However, it often transpired that the kindergarten had no vacancies and the participants had to look for work elsewhere.

\footnotetext{
${ }^{4}$ Adecco is the largest Human Resources provider and temporary staffing firm in the world.
} 
In general, the participants were satisfied with their work in kindergartens. However, many of them experienced difficulties that stemmed from their inadequate knowledge of language and cultural differences. They also highlighted difficulties in their relationships with Norwegian employees. Most participants were aware of the language issue and for this reason preferred to work with the youngest children in order to avoid communication problems. One of the participants explained:

"In terms of the language I was not confident enough to look for work with older children or in a school. Because I'm a qualified teacher, so I kind of have the basic knowledge of education, but you have to be able to talk to children or youth, my language insufficiency could mislead the children...I would like to avoid a situation in which I'm not able to communicate what I want to say. However, with young children, not only words matter, but also gestures, behavior, an intervention in a tough situation, or just a maternal-like care." (1)

The participant's concerns about the fact that her lack of language skills would negatively affect children were not isolated. One of the women was very stressed due to her language incompetence, but she received support from another kindergarten employee:

"In the beginning, I was a pretty scared, because I didn't know the language, and I was working with children and so on. But the teacher who was working there, she calmed me down. She said that as long as I'm playing with and focusing on the children, it doesn't matter to them if I know the language or not. So that really did put me at ease."(6)

Poor knowledge of Norwegian made it difficult for participants to communicate with other kindergarten employees. In Norway, it is not enough to speak Norwegian, but one must also be familiar with the dialects which function there. One of the interviewees explained:

"But also, people speak in different dialects...I was always nervous when speaking to them. One, kind of under his breath, the other also kind of trailed off. I was nervous. I was calm when I was with the children. Because I knew that I'd manage somehow. (7)"

Some of the interview participants characterized their relations with colleagues as positive. They were referred to as "correct", "professional", "easy" or "very good". The other participants experienced difficulties in either relations with the headmaster or with other assistants. One of them pointed out that she was treated differently by older and younger employees:

"...The experiences from work were also stressful. Because the young people kind of stuck together, for a cigarette or something. The older people were curious, so they gladly stayed with me in the room during the break and asked me questions... They asked and asked. But at least I got some practice in speaking because of that. But the younger 


\section{SM̂PP}

people just stayed somewhere to the side. It was hard for me to break through this barrier, so I'd feel more comfortable. (7)

Another woman, when asked about relationships with colleagues, mentioned a boss who had a difficult character. The participant initially wondered if the boss's negative attitude towards her was caused by her poor language skills and foreign origin. Then she tried to explain the boss's behavior with the fact that the boss was half-Italian. It turned out, however, that other employees of the kindergarten also had negative experiences with the headmistress. A number of the participants admitted that they had been discriminated against and exploited at work. This was primarily at the beginning of their kindergarten work. One of the women related the following about her experiences:

"I remember that after three months, just when I started - I remember I received a task. What an assistant should do. After three months. Where for the first three months I slaved away for them all, and no one said a word. Because, I don't know. It seemed to me that I was needed everywhere because they didn't react. After a month I said to my husband, that I think I'm going to quit because I'm too exhausted. My back hurt, my body was giving out. But the boss once noticed and took me aside and said, "You know what? $X$ is also an assistant and she's on your level. You're to listen especially to these two people, ok?" Oh, nice to know... That's when the department boss printed out what should happen. And then we started working with this. The first shift does this, so I figured that I'm backing out, and I won't be doing anything over 100\% because there's no need. That's how I began to learn... But that's how the Poles are-but the Poles, but... when someone new starts, they like to do their best. And especially us. And so I say if someone's hiring an apprentice and they're Polish, they're really in demand. If a person's Polish, then, gladly, because they know that he or she will work hard." (7)

The participant felt exploited because at the beginning of her work she did not know the scope of her duties. She tried very hard to work well and, as a result, she also performed her colleagues' duties. Consequently, she was tired and had a sense of injustice. Only the boss's reaction gradually led to the normalization of the situation. Another woman, declaring that her relationships with other employees and with the boss were very good, wondered if she would be so kind and open if she had a colleague from Romania working in a Polish kindergarten. She admitted that when she worked as a substitute worker at the beginning "it was all so chaotic sometimes" (10). After completing various courses, her situation stabilized, and she learned her responsibilities.

In the statements of many participants there was an appeal to the dichotomy of "us" and "them". One of the women stated that "they", the Norwegian assistants, work much less than "us", Poles but succeed in pretending to be overworked:

"And the best thing is that they're always putting on a show that they're doing something. I'd do a task like that in ten minutes, and for them it's like an hour or an hour 
and a half. I sometimes look to see where my colleague is. She's walking around always doing something. So it's hard to tell her to come over because some other thing, or someone needs help outside. She's always busy. They're clever. They know how to blend in. They're able to respect themselves. Something we aren't able to do, we learn after some time." (7)

The ambivalence of the participant towards her Norwegian colleagues is very interesting. On the one hand, she condemns their behavior, and on the other hand, she admires it, admitting that Polish employees must learn to respect themselves. Another participant's narration shows that, with time, Polish women changed their attitudes towards work and started to value their own health. The participant experienced pressure from the management to get back to work as soon as possible while she was on sick leave:

"I've been in a situation numerous times that when I called in sick, I would get numerous texts and calls asking how I felt. At a certain moment, feeling pressured and guilty from these calls, I'd go back to work not exactly healthy. Without using up my sick leave...so I don't do that any-more. Since I had my back injury and I went on a leave of absence, they finally understood that it's a serious condition and they even forbid my colleagueI heard from a third party — from calling me at home." (9)

With time, the participant learned about her rights, she began to demand their implementation and learned to take care of her own health at work.

Some participants thought that the Norwegian assistants went on sick leave too often, which, in their opinion, showed that they were irresponsible. There were attempts to explain this phenomenon. One of the women admitted that while working temporarily in a kindergarten, she understood the frequent sick leaves of employees:

"The staff changes very, very, very often. A lot of people just don't show up to work. I understand it now, after two years of work in kindergartens, that you can simply be tired and would like to be sick. It doesn't sound necessarily nice, but this work, it's just very demanding. With physical involvement and mental commitment." (8)

Another participant stated that, unlike foreigners, Norwegians do not have to try so hard at work:

"They are honest workers, they come to work, they care about their job, and when I look at other kindergartens somewhere on the way, there really is a lot of foreigners working, maybe it's because being here we pay attention to our jobs more, because we care about them more, and the Norwegians not necessarily do, because there is always NAV (Norwegian Labor and Welfare Administration) or some other institution to help them. Here Norwegians have, obviously, special treatment, it's their country and their rules. We are visitors, so we have to somehow adjust and find our way." (1) 


\section{SM̂PP}

In the participant's words, the "us" category covers not only Poles, but all foreigners who are not at home in Norway and must adapt to the rules applicable in the new society.

To sum up, the results of the conducted research indicate that work in a kindergarten is the next stage of a professional career in Norway for the participants. Most often, however, this is not a dream job but one of the few jobs available. According to research conducted in the UK, Polish female migrants were considered to be very good, reliable and efficient workers (Slany 2008). Polish workers in Norway are rated in a similar way. According to the participants of our research, the diligence and responsibility of Polish women contributes to their exploitation at work and discrimination. Similar experiences have also been voiced by Polish nurses working in Norway (Riemsdijk van 2008). They were in a very unfavorable position in terms of opportunities for professional development. They experienced exclusion and discrimination not only on the part of co-workers but also from Norwegian society as a whole. The kindergarten assistants who participated in our research believed that the best solution is to adapt to the Norwegian style of work and to respect yourself.

As work as a substitute worker in a kindergarten was not so much a matter of choice as one of necessity, the question arises as to whether the participants of the study intend to be associated with this work for a long time or whether they intend to look for employment in other sectors in the future.

\section{5. "Anyone can work in a Norwegian kindergarten." The future career plans of Polish kindergarten assistants}

Statistical analysis show that Polish migrants have experienced relatively limited career options in Norway (Iglicka, Gmaj 2014). The authors state that their options are confined to temporary, atypical forms of employment, that they are exposed to less favorable treatment and that Norwegian labor market is mainly open for Polish unskilled workers (ibid.: 16).

The participants were aware that work as a kindergarten assistant was not associated with promotion in the Norwegian society. It is not a prestigious form of employment and does not generate high salaries. At the time when the research was carried out, candidates for kindergarten substitute worker positions were not required to have a higher education. One of the participants stated that "an assistant can be someone from the street". It was not until 2019 that regulations were introduced in Oslo that an assistant applying for a job in a kindergarten must have at least a secondary education. From 2012, a candidate for an assistant in a kindergarten was required to speak Norwegian at a B1 level. In 2019, the requirements were slightly stricter, and now a person applying for work in a kindergarten must be between B1 and B2 on the CEFR level. 
Despite the low prestige of the assistant profession, only some of the women participating in the research declared their willingness to change their professional situation. A young woman who had been working in a kindergarten for 5 years, was encouraged by the headmistress of the kindergarten to pursue her education further. As a result, she decided to apply to the Utdanningsdirektoratet (The Norwegian Directorate for Education and Training) in order to get her diploma in pedagogical studies from Poland recognized in Norway.

"Yes, she wanted me to study but I figured it was pointless to start another five years since I have already got five years done. So I wanted to find out what it's called, Utdanningsdirektoratet, or something like that. So I checked online, and I wanted them to check my paperwork. If I'm allowed to work at a kindergarten with my education as a special education teacher." (4)

Only after five years of work did the participant decide to apply for the authorization of her diplomas from Poland. The education she had obtained in Poland would significantly facilitate her promotion to a pre-school teacher. A higher salary, greater prestige and increased professional development opportunities are associated with this kind of promotion. The interviewed woman explained that she had not wanted to spend her time on the diploma authorization because she was not sure how stable her job was in the kindergarten. In addition, she did not know how to apply for such an authorization and it was only her boss's support which motivated her to act. Another participant signaled that she wanted to change something in her work having been prompted to do so by provocative comments from her colleagues:

"That's how I've gotten by so far. We'll see. Because I really want to get into it. I've looked at a couple of ads. So I'm becoming more determined that I'll start looking for something else. Sometimes someone will make me angry at work and will point out that I'm just an assistant. And it bothers me. I know that I can't be anything more without a degree in education." (7)

One of the interviewed women, because she was afraid of losing her job, remained in the kindergarten until the return of her predecessor who was on sick leave, despite having enjoyed an extremely difficult relationship with the headmistress. Working in a kindergarten gave her a sense of security, although it was a source of stress at the same time:

"If I had still been working there, I wouldn't have looked for another job. This is why I was happy, because I wanted to look for another job, and as long as I was working there, I wouldn't have looked for another job, but it would've gotten worse and worse with me psychologically from having to try to put up with that boss." (5)

The participant's statement proves that working in a kindergarten was akin to 204 a trap for her because it somehow released her from the obligation to look for 


\section{SM̂PP}

a job. She explained further that the Norwegian labor market is very difficult for migrant women and it would be irresponsible to voluntarily quit a job at a kindergarten. Although the work as an assistant in a kindergarten was not a dream job for most participants, was not consistent with their education, and was connected with deskilling, they tried to retain it and were afraid that they would not be able to find another job.

\section{Conclusions}

The aim of any qualitative research on migration phenomena is not to look for specific trends or behavioral patterns, but to show the actions and functioning of individuals in specific contexts. The research discussed in this article shows the diversity of migratory experiences and confirms that each immigrant has his or her own unique story to tell. The population of Polish female migrants in Norway is very diverse in terms of the reasons for migration, current professional career and future professional plans.

Many Polish women worked in Western countries even before Poland's accession to the European Union. Their status was usually unregulated due to difficulties with legalizing their stay. The research discussed in the article shows that post-accession Polish migrant women often worked without registration, not only at the beginning of their stay in Norway. The most important factor hindering the professional mobility of Polish migrants was an insufficient knowledge of Norwegian. However, the lack of a linguistic competence in Norwegian does not stop migrants from entering the Norwegian labor market. Many women have found employment in the cleaning services sector despite the lack of language competences. Unfortunately, ignorance of the language means that immigrants are more frequently victims of exploitation and fraud on the part of employers.

For the majority of women participating in the research, pre-school work was the second stage of their careers in Norway. However, in most cases it was not "a dream job". Having "any job" at the beginning of their stay in Norway allowed some migrants to learn the language and find out how the Norwegian labor market works.

Bygnes and Bivand introduced the concept of grounded lives, which refers to migrants searching for "stability and predictability that fluid and liberalised working life can hinder" (p. 105). Although in Norway, as in other countries, migrants experience poor working condition, and low pay, they do not decide to return to the country of origin after all. This is due to many reasons, inter alia, the quite favorable legal regulations in Norway that protect employees in the event of job loss or incapacity to work. High unemployment benefits allow many migrants to cover the costs of living in Norway and continue to send remittances home. Some of the women participating in the research, university graduates, were afraid to look for a job in Poland because of the awareness of the difficulties that are associated with it. For many of them, 
deskilling was not a problem at the beginning of their stay in Norway. It seemed more important to have "'any job" to serve as a kind of trampoline when there was a desire and the possibility of professional promotion at some point.

The findings suggest that a number of Polish female migrants in Norway are trapped in employment reserved for migrants. Some of the participants did not seem to be stuck in their employment situation. They were making active efforts to look for better jobs and/or to increase their competences, something in line with the approach of looking at migration as the realization of individual life projects (Christensen, Guldvik 2014). New migrants are able to take advantage of the existing opportunities in the country of immigration and thus consciously build their careers.

It should be borne in mind that migration and its accompanying phenomena are dynamic and that the situation on the European labor markets is also constantly changing. As a result, it is difficult to predict the future career paths of Polish female migrants in Norway.

\section{References}

Anderson B., Ruhs M., Rogaly B., Spencer S. (2006), Fair enough? Central and East European migrants in low-wage employment in the UK, York: Joseph Rowntree Foundation.

Aziz K. (2015), Female migrants' work trajectories: Polish women in the UK labour market, Central and Eastern European Migration Review, 4(2), pp. 87-105.

Braun V., Clarke V. (2006), Using thematic analysis in psychology, Qual Res Psychol., 3(2), pp. 77-101.

Bygnes S., Bivand Erdal M. (2016), Liquid migration, grounded lives: considerations about future mobility and settlement among Polish and Spanish migrants in Norway, Journal of Ethnic and Migration Studies, 43(1), pp. 102-118.

Christensen K., Guldvik I. (2014), Migrant care workers: searching for new horizons, Farnham: Ashgate.

Conradson D., Latham A. (2005), Transnational urbanism: attending to everyday practices and mobilities, Journal of Ethnic and Migration Studies, 31(2), pp. 227-233.

Employment among immigrants, registered-based, Statistics Norway, https://www.ssb.no/en/innvregsys (Accessed: 02.08.2019).

Favell A. (2008), The New face of East-West migration in Europe, Journal of Ethnic and Migration Studies, 34(5), pp. 701-716.

Friberg J.,H. (2010), Working conditions for Polish construction workers and domestic cleaners in Oslo: segmentation, inclusion and the role of policy, in: Black R, Engbersen G., Okólski M., Pantiru C. (eds.): A continent moving West?, Amsterdam: Amsterdam University Press; pp. 38-40.

Grabowska-Lusinska I., Jazwinska-Motylska E. (2013), Znaczenie migracji w życiu zawodowym kobiet i mężczyzn, Kultura i Społeczeństwo, 3, pp. 85-108.

Iglicka K., Gmaj K. (2014), Poland - past and current migration outflows with the special emphasis on Norway. Reports and Analyzes, Centre for International Relations, http://www.transfam. socjologia.uj.edu.pl/documents/32445283/33173123/Rep... (Accessed: 02.08.2019). 
Morokvasic M. (2003), Transnational Mobility and Gender: A View from past-wall Europe, in: Morokvasic, M., Umut, E., Shinozaki, k. (eds.): Crossing Borders and Shifting Boundaries, Vol. I. Gender on the Move, Opladen: Leske und Budrich, pp. 101-136.

Parrenas R.S. (2015), Servants of Globalization: Women, Migration and Domestic Work, Stanford CA: Stanford University Press.

Parutis V. (2011), Economic migrants or transnational middling?: East European migrants' experiences of work in the UK, International Migration, vol. 52 (1), pp. 36-55.

Pustulka P., Bell J., Trąbka A. (2019), Questionable insiders: changing positionalities of interviewers throughout stages of migration research, "Field Methods", vol. 31(3), pp. 241-259.

Riemsdijk M. van. (2008), Immigration, belonging and the politics of difference: Narratives of Polish nurses in Norway, PhD dissertation. Department of Geography, University of Colorado. Slany K. (2008), Female Migration from Central-Eastern Europe: Demographics and Sociological Aspects, in: Morokvasic M., Münst A.S., Metz-Göckel S. (eds.): Migration and Mobility in an Enlarged Europe. A gender Perspective, Opladen: Barbara Budrich, pp. 27-51.

Trevena P. (2011), A Question of class? Polish graduates working in low-skilled jobs in London, Studia Migracyjne: Przeglad Polonijny, 37 (1), pp. 71-96. 